\title{
Addressing Water Concerns Through Spatial Planning Initiatives For Rural Communities
}

\author{
Hildegard E. Rohr \\ Faculty of Natural Sciences, North-West University, Potchefstroom, South Africa
}

\section{Email address:}

21082197@nwu.ac.za

\section{To cite this article:}

Hildegard E. Rohr. Addressing Water Concerns Through Spatial Planning Initiatives For Rural Communities. Agriculture, Forestry and Fisheries. Special Issue: Planning for Sustainable Communities: Green-Spaces in Rural Areas. Vol. 4, No. 4-1, 2015, pp. 52-58. doi: 10.11648/j.aff.s.2015040401.17

\begin{abstract}
Planning in South Africa operates within a legal framework, which strives to ensure that municipalities deliver their developmental duties (in terms of Section 153 of the Constitution). South Africa's approach to Spatial Planning and Land Use Management is undergoing major changes in order to escape from the legacy of apartheid planning, as well as to ensure sustainable development and better management of municipal land. Developing countries such as South Africa do not have the luxury of centuries of learning to adapt to growth. There is no better time than the present to introduce innovative, multidimensional and effective evidence based planning practices by improving the connection between research and professional work to support sustainable development and to overcome the urban and rural challenges presented by rapid population growth. For the first time in the history of South Africa it has been legislated that municipalities must include previously secluded rural areas into their planning strategies. These strategies must take place with a full understanding of current and future challenges such as demographic; environmental; economic; social-spatial; and institutional challenges in order to foster sustainable development. This research will present opportunities in terms of planning for sustainable water management in rural areas (which also includes previously secluded townships) through the use of spatial planning tools such as a Spatial Development Framework and a Municipal Land Use Scheme based on the context of the Spatial Planning and Land Use Management Act No. 16 of 2013.
\end{abstract}

Keywords: Spatial Planning, Water, Rural Communities, Spluma, Sdf, Lus

\section{Introduction}

Among the greatest challenges of the twenty-first century is the increasing population growth [1]. South Africa stands as the second most populous country in the Southern African Development Community, after the Democratic Republic of Congo [2]. From an environmental perspective, as countries continue to grow, they place growing pressure on land,energy and natural resources (especially water), which can lead to greater environmental threats. South Africa is already rated as being the $30^{\text {th }}$ driest country in the world [3]. This is due to low levels of rainfall, $450 \mathrm{~mm}$ per annum relative to the world average of $860 \mathrm{~mm}$ per annum, [3] and high level of evaporation due to the temperatures of annual mean above $17^{\circ} \mathrm{C}$ [4]. With a population growth rate of 1 percent per year, key demographic observations indicate that South Africa's population will reach an estimated population total of 83,6 million in 2050 [5]. Population and economic growth inevitably creates more demand for water. How and where that growth takes place affects how much additional water is needed and how much it will cost to deliver.

The Department of Water Affairs (DWA) has embarked on a nationwide water-reconciliation study. The DWA found that surface water availability and its remaining development potential will be insufficient to support the growing economy and associated needs in full. Water development potential only exists in a limited few water management areas, whilst serious challenges remain in the majority of water management areas [6].

Consequently, countries around the world, including South Africa, have been actively seeking environmentally sustainable solutions through sustainable development planning practices, with water sustainability being one of the major priorities. The USA formulated the concept of 
Low-Impact Development (LID), the UK's approach was Sustainable Urban Drainage System (SUDS), and New Zealand formulated their approach as Low Impact Urban Design and Development (LIUDD) [7].

Aiming to integrate all of the above mentioned approaches, Australia developed the concept of Water Sensitive Urban Design (WSUD). WSUD refers to the interdisciplinary cooperation of water management, urban planning, urban design and landscape planning which considers all parts of the urban water cycle, combines water management functions and urban design approaches and facilitates synergies between ecological, economic, social and cultural sustainability [8]. It bridges gaps between various sectors and provides a platform for trans-disciplinary planning, which is a challenge for sustainable water resources management in municipalities. The South African Water Research Commotion (WRC) recently published "Water Sensitive Urban Design for South Africa: Framework and Guidelines" based on the concept of Australia's WSUD, as a first attempt at guiding South Africa's settlements in becoming more water sensitive. Brown, et al., (2009) raised concerns that even though international best practices will be fit for purpose in formally-developed areas in South Africa, rural settlements are not being catered for [9]. South Africa cannot rely on purely international guidelines. South Africa's history and geographic makeup, linked with its unique climate, requires guidelines that are fit for local circumstances.

\section{Rural South Africa}

\subsection{Rural Neglect}

Rural areas present a number of challenges for the modern society as they are generally associated with the legacy of apartheid. In the 1910's South Africa consisted of four provinces. The segregation of the Black population through the concept of "apartheid" started in 1913, with ownership of land by the Black majority being restricted to certain areas known as "homelands" or "Bantustans" (today, better known as rural or traditional areas) [9]. In essence, the Apartheid State refused to acknowledge "Africans as permanent urban inhabitants...investment in housing, infrastructure, education and other essential services in the townships was pared back from an already low level, in order to eliminate any such attractions the cities might offer to people from rural areas" [10]. This resulted in significant backlogs in infrastructure.

After the first non-racial elections in 1994, the country's adoption of the first Interim Constitution made it possible for Provinces and homelands to merge, thus giving birth to the current nine provinces of South Africa. In 2000 the re-demarcation of the country's "wall-to-wall" municipalities were created thereby including all intervening land between the towns or former transitional local councils [9]. Even though this meant that rural areas were now included in the municipal boundaries, town planning practices (spatial development frameworks and land use schemes) were still limited to former town boundaries (excluding the rural or traditional areas).

\subsection{Changing Legislative Perspective}

South Africa's planning history has seen a considerable array of legislation. Much of the legislation responsible for managing land uses in a municipality pre-dates 1994. Settlements in these rural areas was governed by Legislations such as the Development Facilitation Act No 67 of 1995 (DFA) and the Less Formal Township Establishment Act No 113 of 1991 [9]. In theory, these pieces of legislation directed planning authorisation in rural areas to Provincial Development Tribunals. Constitutional Court found sections of post 1995 legislation (DFA, 1995) invalid based on unconstitutionality. As a result, The Department of Rural Development and Land Reform published the Spatial Planning and Land Use Management Bill in 2012, which was enacted in 2013.

The Spatial Planning and Land Use Management Act No. 16 of 2013 (SPLUMA) repealed the DFA in its entirety. One of the key principles of the Act is the active pursuit of sustainability through the promotion of integrated planning and the involvement of various sector departments in formulating planning documents at various levels of government. Furthermore, the Act states that municipalities must adopt a single "wall-to-wall" Land Use Scheme and Spatial Development Framework including the previously secluded rural areas [12].

\subsection{The Rural Reality}

Statistics South Africa defined rural areas as "Any area that is not classified urban". Census 2011 indicated that 63 percent of South Africa's population resides in urban areas, 32 percent in rural areas and 5 percent of the population in commercial farming areas [13]. Map 1 below presents the geographic extent by South Africa's geo-type. The red areas in the Map 1 represents the country's rural areas, yellow represent urban and the light green areas are commercial farmland.

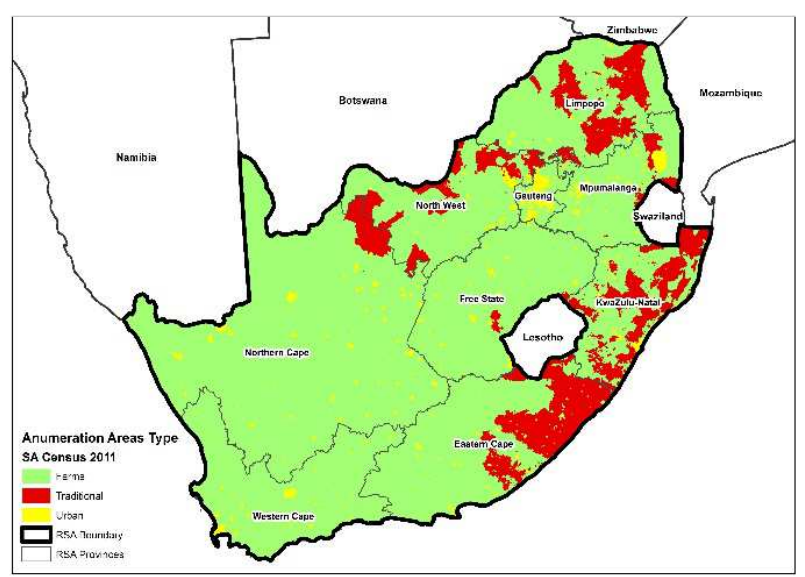

Map. 1. Geographic extent of enumerated area type.

Even though the majority of the population resides in urban areas, the geographic extent of these populated areas paints a 
different story. Table 1 sets out the geographic extent of these areas in hectare and percentage of land coverage. Rural areas in South Africa covers 13 percent in comparison to the urban areas which is only a small 3 percent and commercial farming 63 percent. Placing this information in perspective, spatial planning practices in South Africa has ignored 13 percent of its vitally important populated geographic area.

Table 1. South Africa Geo-type.

\begin{tabular}{lll}
\hline Geographic type - Enumerated Area & Hectare & \% of cover-age \\
\hline Farms & 103345006 & $84 \%$ \\
Rural / Traditional & 15740885 & $13 \%$ \\
Urban & 3746130 & $3 \%$ \\
South Africa Total Areas & 122832021 & $100 \%$ \\
\hline
\end{tabular}

Municipalities cannot afford to ignore the population that resides in the previously unplanned rural areas. The South African Constitution states that municipalities have the responsibility to make sure that all citizens are provided with services to satisfy their basic needs, e.g. water, electricity, refuse removal, etc. These services have a direct and immediate positive impact on the quality of the lives of the people in that community. It is no secret that underlying tension between rural/traditional and municipal leadership exists. This is mainly due to the ideological paradigms sometimes depicted as "African versus western" or "customary versus individual civil rights" frameworks. That said, rural areas presents major challenges for town planners, some of which includes the following:

- There is a lack of spatial information and data necessary for planning exercises.

- Geographically these communities are inaccessible and far from urban centers.

- Communication presents a barrier as little English is spoken or understood in the majority of these areas.

Issues of land management and ownership are viewed with suspicion by traditional leaders, making any form of spatial planning rather difficult.

Adding to the strain of planning for rural areas is the fact that rural areas are faced with many spatial structuring elements which cannot be changed, generally referred to as the inefficient rural form.

\subsection{An Inefficient Rural Form}

Rural settlements which are commonly associated with large plots, low density, and dispersed development all increase the cost of delivering conventional water infrastructure. Other factors in terms of planning for infrastructure and the increasing cost thereof include:

- Reconstruction and Development Programme - RDP (though well intended) places a burden on existing water sources as this is often accompanied by policies such as free basis service delivery or an unaffordable high level of service.

- Low-density, dispersed development requires longer pipes, which lose more water through leakage and raise transmission costs $(6-25$ percent $)[12]$.
- Infrastructure investment that supports water system expansion instead of upgrading and maintaining existing networks can lead to increasingly inefficient systems, greater waste, higher capital and operating costs [13].

- Location of development beyond urban development boundary can reduce return on investment in infrastructure - Adding new developments to the existing network spreads the system's capital costs over a larger customer base, lowering the cost of water service per customer [14].

- Inappropriate land use near water sources could potentially lower downstream water quality (for example locating landfills near aquifers) [13].

- Service costs associated with water infrastructure are strongly influenced by a development's location and density. Therefore, any new system should be located within existing, growing communities (in the form of infill development) as opposed to the creation of new infrastructure on the periphery of the urban boundaries [14].

There is a need to use a different approach when dealing with rural areas. Rural areas have resources that are unique form the urban areas and that gives them a comparative advantage, however the exclusion of rural areas into municipal planning and incoherent development approach has made rural areas seen as unworthy, hopeless areas where growth and development can never happen. Land Use Management System will be incomplete if rural areas are not included in the municipal planning processes.

\section{Current Institutional and Legislative Context}

The management of water sources (dams) currently happens at a national level through the DWA. The distribution of water from its source to its clients is the constitutional responsibility of local government (metros, local or district municipalities) who act as the water services authorities and often also water service provides for all communities in their areas of jurisdiction. Plans at this level includes water services development plans (WSDP) which must be updated on an ongoing bases. The WSDP integrates technical, social, institutional, financial and environmental planning and feeds into the integrated development plan process [6].

Spatial planning (to date) happens at a municipal or district municipality level through the Spatial Development Framework. In theory the SDF must be aligned to the integrated development plan (same as the WSDP). Land uses are managed on a municipal level through a land use scheme (also called zoning code, zoning scheme or town planning scheme) [15].

Reviewing the above, it would seem as if all basis are covered. In practice, very little (if any) of the above plans are in fact not aligned with each other. The result thereof is that planning for water supply and planning for water demand (as expressed through population and land use growth) is 
disconnected [16]. An example of this can be seen in the Greater Tubatse Municipality in South Africa, where large planned developments (to accommodate an urbanising population) never happens due to the unavailability of bulk water [15].

\section{Changing legislation Spatial Planning and Land Use Management Act}

Recent court cases involving land use management and urban planning in South Africa led to the development of the new and recently enacted SPLUMA. As stated earlier, one of the key principles of the Act is the active pursuit of sustainability through the promotion of integrated planning and the involvement of various sector departments in formulating planning documents at various levels of government [11].

- A National Spatial Development Framework (NSDF) must take into account policies, plans and programs of public and private bodies that impact on spatial planning, land development and land use management (for e.g. the national water resource strategy).

- Provincial Spatial Development Framework (PSDF) which must be consistent with the NSDF. The PSDF must coordinate, integrate and align provincial plans and development strategies with policies of national government, provincial departments and municipalities (this could also imply, policies and plans developed by water service authorities whose boundaries overlaps with local municipal boundaries).

- $\quad$ The Municipal Spatial Development Framework (MSDF) must give effect to the development principles and applicable norms and standards set out in Chapter 2 (this include the principle of sustainable development as mentioned earlier in this document). The MSDF must identify, quantify and provide location requirements of engineering infrastructure and services provision for existing and future development needs for the next five years (water provision for sustainable development). The MSDF must provide the spatial expression of the coordination, alignment and integration of sectoral policies of all municipal departments (most importantly water management).

- Municipalities must also adopt a land use scheme that gives effect to and be consistent with the municipal spatial development framework and determine the use and development of land within the entire municipal area.

It is critical that sector departments from different spheres of government as well as utilities and agencies communicate with one another.

\subsection{Planning for the Future Water Sensitive Planning Exploring the Options}

Spatial planning and land use management must value water as a natural resource playing a critical role in the overall sustainability of the municipality. South Africa has been given a golden opportunity to adopt a water sensitive planning approach, which includes rethinking the role of strategic spatial planning and land use management and its obligations towards water in the built environment.

Water sensitive planning ensures that development interacts with the hydrological cycle in ways that: provide the water security essential for economic prosperity through efficient use of the diversity of water resources available; enhance and protect the health of watercourses and wetlands; mitigate flood risk and damage; and create public spaces that harvest, clean and recycle water [17]. Given the new planning environment as stipulated by SPLUMA, this section will specifically focus on the proposed content of SDF's and a land use scheme and how this can contribute the sustainable planning for the management of water.

\subsection{Integrating Water Sustainability Through Innovative Spatial Planning Management Tools}

A Spatial Development Framework (SDF) is the principal strategic planning instrument which guides and informs all planning and development, and all decisions with regard to planning, management and development in the municipality. An SDF is a document accompanied by a set of plans that illustrates the future spatial form of the municipality. It uses tools such as nodes and corridors and concepts such as densification, containment, protection and growth areas to indicate how land uses in the municipality must be managed to arrive at this future spatial form. Keeping in mind that rural areas have always been excluded from this planning instrument, SPLUMA now legislates that a municipal SDF must include preciously secluded rural areas.

In the section below, the legal requirements for a municipal SDF (highlighted in bold) will be discussed with specific reference to water sensitive planning. SPLUMA, in section 21 specifies the content of a municipal spatial development framework as consisting of the following [11].

Section 21(A) Give Effect to the Development Principles and Applicable Norms and Standards Set out in Chapter 2

One of these principles includes sustainability. Climate change is affecting the sustainability of South Africa's natural resources, especially the availability of water sources. Climate change is not only about the change in the earth's system, it is also about the impact of these changes on vulnerable communities. The impact on both rural and urban communities, particularly in the absence of effective risk reduction strategies, are expected to be significant in changing climate scenario and require an effective response. In communities where access to clean water is already a problem, a slight decrease in rainfall has an amplified effect. Water being a scare natural resource in South Africa is one of the major reasons why municipalities are currently unsustainable. Planning should therefore address this at a policy level.

Section 21(B) Include A Written and Spatial Representation of A Five-Year Spatial Development Plan for the Spatial Form of the Municipality

The spatial development pattern consists of land uses. 
Urban and rural land users consume water. Therefore the decisions regarding the spatial patterns should also consider the availability of water and the impact on water resources. Pro-active planning and water management can contribute to sustainable allocation of water and optimal development of water infrastructure. By aligning development priorities with the availability of water in the municipal area, municipalities will be able to make provision for new infrastructure of redirect development to better allocated locations.

Section 21(C) Include a Longer Term Spatial Development Vision Statement for the Municipal Area Which Indicates a Desired Spatial Growth and Development Pattern for the Next 10 to 20 Years

See the point made above. This longer term spatial vision should, however, also incorporate the longer term outlook of water availability as well as changing climate considerations such as global warming and its impact on water sources.

Section 21(D) Identify Current and Future Significant Structuring and Restructuring Elements of the Spatial Form of the Municipality, Including Development Corridors, Activity Spines and Economic Nodes Where Public and Private Investment Will Be Prioritised and Facilitated

Corridors, activity spines and economic nodes can either mean future development or redevelopment and is not only limited to urban areas. Water sensitive planning includes the development of blue and green corridors which integrates the different land uses and stakeholders through the development of surface water mitigation measures. Blue-green corridors imply retaining stormwater from small, frequent rainfall events as the source of public-, residential- and commercial buildings, through the use of source and site control measures such as rainwater harvesting, green roofs or rain gardens.

Municipalities and National Departments are responsible for delivering community facilities e.g. Department of Education is responsible for the provision of schools. These community facilities can be designed as a rainwater harvesting structure, providing water for users within the facility. Many will argue that this approach will be too expensive, and that budgets are not capable of catering for these request. Fact is, research has proven that the long-term benefits of water harvesting systems overwrite the short-term construction cost [20].

Section 21(E) (F) Include Population Growth Estimates as Well as Estimates of Economic Activity and Employment Trends and Locations for the Next Five Years

This is most important in order to quantify future water demand. If the population growth and water allocations do not match, serious considerations must be given to innovative rainwater harvesting technologies. Municipalities must identify the development pressures presented by local economies. The vision must be supported and aligned with the water service delivery plan of the municipality. Growing rural population also increases the need for food security, which in essence means more pressure on water sources. Today, an estimated 14 million people of about 35 percent of the country's population are vulnerable to food insecurity. Alternative approach such as improving food security with less water should be explored in rural areas.

Section 21(H) Identify, Quantify and Provide Location Requirements of Engineering Infrastructure and Services Provision for Existing and Future Development Needs for the Next Five Years; Include an Implementation Plan Comprising of Sectoral Requirements, Including Budgets and Resources for Implementation

Knowing the cost of water utilities and the cost of water infrastructure can have a significant impact on the size, location and density of development. Often land use planning or proposals are done without taking into account the availability of infrastructure or the cost of establishing adequate bulk infrastructure and reticulation. This should in fact be an iterative process. The planning scenario should be measured against the infrastructure cost, if the answer exceeds available infrastructure or the cost of establishing capacity, the planning scenarios should be adapted to be in line with capacity constraints.

Section 21(J) Include A Strategic Assessment of the Environmental Pressures and Opportunities Within the Municipal Area

Preserve open space, farmland, natural beauty, and critical environmental areas. Address water resource issues and conservation of biodiversity at the catchment and sub-catchment level especially in rural areas. Households in rural areas are often located near rivers as it is used as their primary water source. Legally, there should be no development within the 1:100 floodline and where the integrity of a river bank may be compromised. There is no data that exists on the calculations of the floodlines in most rural areas. Spatial development framework and land use schemes can assist Traditional authorities in developing a buffer zone around these river banks, in order to protect households from flooding and also protecting rivers from pollution. Protecting the environment and water sources should be prioritized.

Section 21(M) Provide the Spatial Expression of the Coordination, Alignment and Integration of Sectoral Policies of All Municipal Departments

This very important principle should enforce cooperation between the planning departments and the department responsible for water. Often this is not the case - the spatial development framework (compiled by the planners) and the water services delivery plan contradict each other.

\subsection{Alignment of Spatial Development Framework and a Land Use Scheme}

While an SDF provides an indication of acceptable land uses or intensity of land uses in certain geographical areas, land use rights are managed though a land use scheme. This scheme can be amended to reflect new or additional land uses or land use rights. Because the aim of the SDF is to provide an overview of the future spatial form of the municipality, it is the primary tool used to decide if a change in land use rights (through the amendment of the land use scheme) should be allowed. In the past, this link between planning tools has been tenuous at best, but SPLUMA specifically calls for a stronger linkage by insisting that an SDF: 
- $\quad$ determine the purpose, desired impact and structure of the land use scheme to apply in that municipal area;

- $\quad$ propose (as part of the implementation plan) a list of amendments to the land use scheme that is necessary to achieve the aims of the SDF; and

- $\quad$ propose geographical areas where the normal processes and procedures of changing land use/rights may be shortened as a way to ensure that the spatial objectives of the SDF will be met.

In the section below, the legal requirements for a municipal land use scheme (highlighted in bold) will be discussed with specific reference to water sensitive planning. SPLUMA, in Section 24 specifies the content of a municipal land use scheme as consisting of the following [11].

Section 24(2) (A) Include Appropriate Categories of Land Use Zoning and Regulations for the Entire Municipal Area

Zoning for groundwater protection directs development away from groundwater-sensitive or aquifer recharge areas and prohibits potentially polluting uses. A land use scheme must be aligned with environmental policies and plans, therefore, zoning codes and scheme clauses can and must address site-specific ecological conditions. "Overlay zones" can protect stream corridors, lakeshores, and watersheds thereby maintaining and improving the water quality - even as the community becomes more developed. An overlay zone can protect water quality by setting additional standards for development and by incorporating site-specific review procedures. These site specifics include - building lines, boundaries, densities [18].

Zoning can regulate development by directing development to appropriate locations, requiring development to be setback from riparian areas, limiting the total impermeable site coverage, establishing appropriate lot sizes, limiting or enhancing density, requiring appropriate drainage, and prohibiting potentially polluting uses in areas where aquifers must be protected. This might not be fully accepted in rural areas as these urban-planning related terms are typically associated with "western thinking" but an incremental introduction of these land use management guidelines will benefit all.

Protect ecological and hydrological integrity - Use natural channel design and landscaping to ensure that the drainage network mimics the natural ecosystem. Control sediment-laden runoff from disturbed areas, in particular during construction of developments. The land use scheme must include groundwater recharge and conservation regulations where environmental management authorities aim to limit impermeable areas, drainage, and keeping permitted uses to those that are non-polluting. Natural channel design and landscaping can include the planting of edible and nutritious food. Opportunities for job creating can be introduces, as this is a familiar activity for farmers in rural areas.

Section 24(2)(C) Include Provisions that Permit the Incremental Introduction of Land use Management and Regulation in Areas Under Traditional Leadership, Rural Areas, Informal Settlements, Slums and Areas Not Previously

\section{Subject to A Land Use Scheme}

The high cost of providing services and infrastructure in rural areas, and especially in places that are remote and have low population densities requires innovative solutions. For example installation of rainwater tanks to collect rainwater to supply toilet flushing and outdoor uses. Many rural municipalities lack the financial and technical capacity to manage water services adequately. Planners must recognise the need for site-specific solutions and implement appropriate non-structural and structural solutions. Minimise the use of hard engineered structures.

Section 24(2) (E) Include Land use and Development Incentives to Promote the Effective Implementation of the Spatial Development Framework and other Development Policies

Provide incentives through the use of rebates for implementation of on-site measures which may reduce the need for drainage infrastructure upgrade. Ensure developments incorporate water efficient appliances (community facilities). Ensure fit for purpose re-use is incorporated on site or in the catchment. More relevant to urban areas than rural areas, Land Use Scheme and development controls have the ability to incentivise developers on a financial or non-financial manner. Typically, in urban areas incentives are linked to existing dwellings or retrofit situations where opportunities for implementing of water sensitive planning and site design elements. Non-financial incentives include for example, increasing the allowable floor-space ration, or increasing the impervious area of a residential allotment, provided the development includes sustainability initiatives such as rain water harvesting, living green walls, water reuse and water efficient appliances.

Section 24(2) (F) Include Land Use and Development Provisions Specifically to Promote the Effective Implementation of National and Provincial Policies and Give Effect to Municipal Spatial Development Frameworks and Integrated Development Plans

Ensure water management planning is precautionary and recognises intergenerational equity, conservation of biodiversity and ecological integrity. Protect waterways by providing a buffer of natural vegetation. Use of native vegetation in all runoff management measures and all landscaping to maximise habitat values.

By developing effective, adaptive and innovative water sensitive spatial development frameworks and land use schemes, sustainable management of the total water cycle in rural and urban areas can be accomplished.

\section{Conclusion}

The link between the land use and provision of infrastructure is evident in the development principles of spatial planning highlighted in the SPLUMA. In order to plan sustainably, spatial planning and land use management systems must consider all current and future water resources, and costs thereof, to all parties for the provision of infrastructure and social services specifically in rural areas. 
SPLUMA also requires that Municipal Spatial Development Frameworks and land use schemes identify, quantify and provide location requirements of engineering infrastructure and services provision for existing and future development in both urban and rural areas. Land development must optimise the use of existing infrastructure and needs to introduce innovative surface- and groundwater protecting tools to fight against the looming water scarcity reality.

The focus of spatial planning in South Africa has been redirected adopt a national, provincial and local municipal planning system which is integrated with all sectors impacting on development. If implemented according to law spatial planning and land use management can and will provide water security for rural and urban communities in near future.

\section{References}

[1] B. Ruble, "The Challenges of the 21st Century City," Wilson Center, Washington, DC, 2012.

[2] Central Intelligence Agency, "The World Factbook SADC region.," 2009. [Online]. Available: https://www.cia.gov/library/publications/the-world-factbook/i ndex.html. [Accessed 02 March 2015].

[3] Department of Water Affairs, National Water Resource Strategy, Republic of South Africa, 2012.

[4] T. McMahon and M. Peel, "Global stream flow Part 3: Country and climate zone characteristics," pp. 347: 272-291.

[5] G. Ara, M. Jonathan, R. Mickey and S. Julia, "Population Futures: Revisiting South Africa's National Development Plan 2030,," Hanns Seidel Foundation, 2013.

[6] Department of Water Afairs, "Strategic Overview of the Water Sector in South Africa 2013," Department of Water Affairs, Pretoria, 2013.

[7] H. E. Rohr, "Water Sensitive Planning - An integrated approach towards sustainable urban water system planning in South Africa," North-West University Potchefstroom, Potchemstroom, 2012.

[8] I. Wagner, "Water Sensitive Urban Design Task Group," SWITCH, 2010.

[9] R. Brown, N. Keath and T. Wong, "Urban Water Management in Cities: Historical, Current and Future Regimes.," in Water Science \& Technology, vol. 59(5), 2009, pp. 847-855.

[10] F. John, "An Introduction to Municipal Planning within South Africa," South Africa Planning Instituete, Durban, 2011.

[11] I. Turok, "Urban Planning in the Transformation from Apartheid: Part 1: The Legacy of Social Control.," in The Town Planning Review, vol. 65(3), 1994, pp. 243-259.

[12] Rural Development and Land Reform, "Spatial Planning and Land Use Management Act No. 16 of 2013," Republic of South Africa, Pretoria, 2013.

[13] Statistics South Africa, "Statistics South Africa," 2010. [Online]. Available: www.statssa.gov.za. [Accessed 27 March 2015].
[14] Calgary Region Focus, "Let's talk density," Calgary Region Focus, 23 Febuary 2013. [Online]. Available: http://www.calgaryregionfocus.com/2013/02/20/lets-talk-dens ity/. [Accessed 4 Febuary 2014].

[15] The World Bank Institute, "Suasainable Urban Land Use Planning- Module 03: How to Integrate Land Use and," The World Bank Institute, Unknown, 2014.

[16] P. Van Lare and D. Arigoni, "Growing Towards More Efficient Water Use: Linking Development, Infrastructure and Drinking Water Policies," United Sates Enviromental Protection Agentcy, Washington DC, 2006.

[17] W. Fourie, Interviewee, Spatial Planning and Land use management in South Africa. [Interview]. 18052014.

[18] Glen Steyn \& Associates, "Greater Tubatse Local Economic Development Strategy," Greater Tubatse Local Municipality, Greater Tubatse, 2007.

[19] CRC, "Water Sensitive Cities," Australian Goverment Inisiatives, Melbourne, 2014.

[20] A. Niel, V. Michael, F.-J. Lloyd, W. Keven, S. Andrew and D. Jessica, "The South African Guidelines for Sustainable Drainage Systems.," Water Research Commission, Cape Town, 2013.

[21] J. Russell, "Overlay Zoning to Protect Surface Waters," 2014. [Online]. Available: $\mathrm{http} / /$ plannersweb.com/2004/04/overlay-zoning-to-protect-sur face-waters/. [Accessed 0206 2014].

[22] Brundtland Commission, "Report of the World Commision on Enviroment and Development," United Nations , 1987.

[23] Robeco \& RobecoSAM, "Measuring Country Intangibles," 2013[Online].Available:

www.robecosam.com/images/CS_Ranking_E_Rel.FINAL.pdf. [Accessed 0304 2014].

[24] UN-HABITAT, Urban Planning for city leaders, 2nd Edition ed., Germany: Swedish International Development Cooperation Agency, 2014.

[25] J. Verbeek, "Developing Countries Need to Harness Urbanization to Achieve the MDGs: IMF-World Bank report," The World Bank, Washington, DC, 2013.

[26] K. Kevin, F. Ann and S. Carissa S, "Is There a Role for Evidence-Based Practice in Urban Planning and Policy?," Planning Theory \& Practice, vol. 10, no. 4, pp. 459-478, 2009.

[27] [National Planning Commission, "National Developemt Plan Vison of 2030," National Panning Commicion , Pretoria, 2011.

[28] American Water Works Association, "Fact sheets," 2004. [Online]. Available: <http://www.awwa.org/pressroom>. [Accessed 10 June 2014].

[29] S. Rhimes, "GoodReads," 2014. [Online]. Available: https://www.goodreads.com/author/quotes/3888197.Shonda_R himes. [Accessed 19 May 2014].

[30] N. Taylor, Urban Planning Theory since 1945, 1st ed., London: SAGE, 1998. 